\title{
WILDLIFE MANAGEMENT UNDER ENCROACHMENT AREA OF SARISKA TIGER RESERVE: A FUTURE CHALLENGES AND OPPORTUNITIES
}

\author{
Pavan Kumar ${ }^{1, *}$, Manmohan Dobriyal ${ }^{1}$, A. K. Pandey ${ }^{1}$ and Meenu Rani ${ }^{2}$ \\ ${ }^{1}$ College of Horticulture and Forestry, Rani Lakshmi Bai Central Agricultural University, Jhansi-284003, India. \\ ${ }^{2}$ Department of Geography, Kumaun University, Nainital, Uttarakhand, India.
}

\begin{abstract}
Wild tigers experience unparalleled coercion due to habitat destruction, prey reduction and commercial poaching. The Indian tiger (Panthera tigris tigris) one of the world's most endangered carnivore species, and is now thought to be in the verge of extinction in the wild. Sariska National Park in India is considered to be a highly suitable habitat for the tigers. Relocation and change in habitat of these living giant creatures is a thought of study for their survival and existence in the coming future considering change in climatic conditions. But the main problem for the tigers in the new habitat will be poaching and the human-wildlife conflicts. Integrated geospatial techniques provide accurate, cost-effective as well as time-effective method for habitat evaluation. The aim of the study is current status followed by opportunities and challenges. The results point out a large and comprehensive research on each of these issues, in particular on the community involvement in wildlife management and government policies.
\end{abstract}

Keywords: Wildlife, Geospatial technology, Sariska tiger reserve, Panthera tigris tigris.

\section{INTRODUCTION}

India is the seventh largest country in the world and Asia's second largest nation with an area of 3,287,263 km2, a national border of 15,200 km, and a coastline of $7516 \mathrm{~km}$. The people of the Indian subcontinent were once blessed with some of the most profuse natural gifts: verdant forests, water-stocked Himalayan ranges, rich coastal fish resources, productive estuaries, grassy pastures, and bountiful river systems (Srivastava, 2009; Walston et al., 2010; Change and Wang, 2009 Gurnell et al., 2002). Years of mismanagement, however, have degraded our forests, wounded our coastline, and poisoned our aquifers with devastating results. Today, India contains 172 species (2.9\% of the world's total number) of animals that are considered to be globally threatened by the IUCN. These include 53 species of mammals, 69 species of birds, 23 species of reptiles, and 3 species of amphibians. Establishment of protected areas (PAs) has been the most widely accepted means of biodiversity and wildlife conservation so far, supported by national and international agencies. However, alarming loss of habitat makes it difficult for wildlife to adapt. The reason for such alarming habitat loss is because international conservation policies have neglected considering niche habitats of species when setting targets for the expansion of protected areas. The global protected area network, which implies forests or other ecosystems protected under law, don't cover the environmental or climatic conditions required by a majority of 19,937 vertebrate species assessed in the study. The loss of Sariska Tigers Reserve (STR) was the most prominently broadcast wildlife story in post-Independence India (Butfiloski et al., 1997; Rittenhouse et al., 2006; Roy et al., 1995; Singh et al., 2009).

Natural forests and wild animals that live in it can still live without the help of humans. Whereas human society cannot maintain its existence for many days in the absence of them

*Corresponding author: pawan2607@gmail.com 
(Kushwaha et al., 2000; Kushwaha et al., 2004b; Larson et al., 2003; Aspinall and Veitch, 1993). As much as centuries of thought have been given to the ancient Indian society about conservation of natural resources and wildlife, it is not even in Western knowledge. But the irony is that today, foreigners are telling us about conservation of nature and wildlife, while conservation of nature is a part of our Indian way of life.

Formerly a dominant part of Sariska's ecology and culture, tigers were missing from some areas of this landscape for decades before being officially declared extirpated (locally extinct) in 2005.In July 2008, two tigers from Ranthambhore National Park were relocated to Sariska Tiger Reserve. Another female tiger was relocated in February 2009 (Sankar et al., 2010). Also, translocations will likely increase in popularity after Jhala et al. (2015) reported a $30 \%$ increase in India's tiger population, now reported at 2,226. Rising tiger populations in isolated protected areas (PAs) pose a conservation concern, as competition for resources can expedite intra-specific conflict (conflict within a species population), prompting translocations. Effective conservation of the endangered tiger depends upon reliable knowledge of factors driving genetic differentiation and population connectivity (Reddy et al 2017). As per state forest department, the major factor which tilted the scales against Sariska, despite the honest intentions with which the tiger relocation programme started here, is the presence of 29 villages inside the reserve, Sariska is on the verge of losing its tigers once again. There is a great need for conservation of wildlife while studying the causes of wildlife loss in STR. it was hypothesized that stress caused by these anthropogenic pressures in the habitat might have an influence on the reproductive potential of the introduced tigers in Sariska and a study was conducted (Bhattacharjee et al., 2015).

This study makes an explorative overview on two main research topics in policies of wildlife management in Sariska tiger reserve: current status followed by opportunities and challenges. The results point out a large and comprehensive research on each of these issues, in particular on the community involvement in wildlife management and government policies.

\section{Wildlife and Environment}

The pressure of development has led us to the brink of environmental crisis today by prudent exploitation and exploitation of natural products that now even the survival of the natural is in crisis. In such a situation, what will be the value of our priceless heritage wildlife? Lack of pure life, degradation of soil origin from contaminated water, fertilizers and synthetic chemicals, shrinking natural forests, increasing temperature due to gaseous pollution in the atmosphere, depletion of organic-borne nutrients in food grains and lack of rainfall, etc. (Bian and West, 1997; Brooks, 1997; Conner and Leopold, 1998; Craighead, 2008). Today, if there is a stroke, then a question mark is automatically put on the conservation of vegetation and wildlife. In other countries of the world, wild animals have been destroyed due to hunting and their neglect. As a result, the number of wild animals and birds has remained very low. Many breeds have perished. Therefore, in such a situation, the need was felt to protect and preserve these wild animals in national parks, protected forest areas. Therefore, like many countries, national parks, sanctuaries have also been established in India (Debeljak et al., 2001; Donovan et al., 1997; Edenius and Mikusinski, 2006)..

\section{Sariska Tiger Reserve : At the verge of loos wildlife}

The Sariska Tiger Reserve (STR), is compromised of the Sariska Wildlife Sanctuary and adjoining areas in the Alwar district of Rajasthan, a state in India (Kumar et al., 2018a; Kumar et al., 2018b; Kumar et al., 2014a; Kumar et al., 2014b; Kumar et al., 2012; Rani et al., 2011) STR stretching for $1200 \mathrm{Km}^{2}$ located between $27^{\circ} 13^{\prime} \mathrm{N}$ to $27^{\circ} 31^{\prime}$ $\mathrm{N}$ latitudes and from $76^{\circ} 15^{\prime} \mathrm{E}$ to $76^{\circ} 33^{\prime} \mathrm{E}$ longitudes (Figure 1). It lies in Alwar district of Rajasthan state in India. Government of Rajasthan (2007) notified three distinct zones in STR viz. critical tiger habitat (881.11 $\mathrm{Km}^{2}$ ), protected forest $\left(276.14 \mathrm{Km}^{2}\right)$ and reserved forest $\left(604.97 \mathrm{Km}^{2}\right)$.

Prior to the formation of the state of Rajasthan, the Reserve was a part of the Alwar princely state, managed solely to supply hunting grounds for the royals. After India's independence, Government of Rajasthan assumed control of the Reserve. The Sariska was declared as a Wild Life Reserve area in 1955 under the Rajasthan Wild Animals \& Birds Protection Act of 1951. The park was brought under Project Tiger in the second phase of the Project's expansion from 1978-79. In 1982, the land was declared as Tiger Reserve. The Ministry of Environment \& Forests (MoEF) issued guidelines to the state government to delineate the Critical Tiger/wildlife habitats in tiger reserves / protected areas. According to the guidelines, delineating of critical tiger habitat (CTH) is required for the sustenance of a viable population of tiger and other wild animals in tiger reserves and protected areas. For supporting viable population of tigers, a minimum inviolate space of 800 $1,000 \mathrm{~km}^{2}$ should be maintained based on tiger life history parameters, territory sizes, and population viability analysis.

According to the tiger census of October 2018 in this national park famous for tigers, there are a total of 18 tigers, 


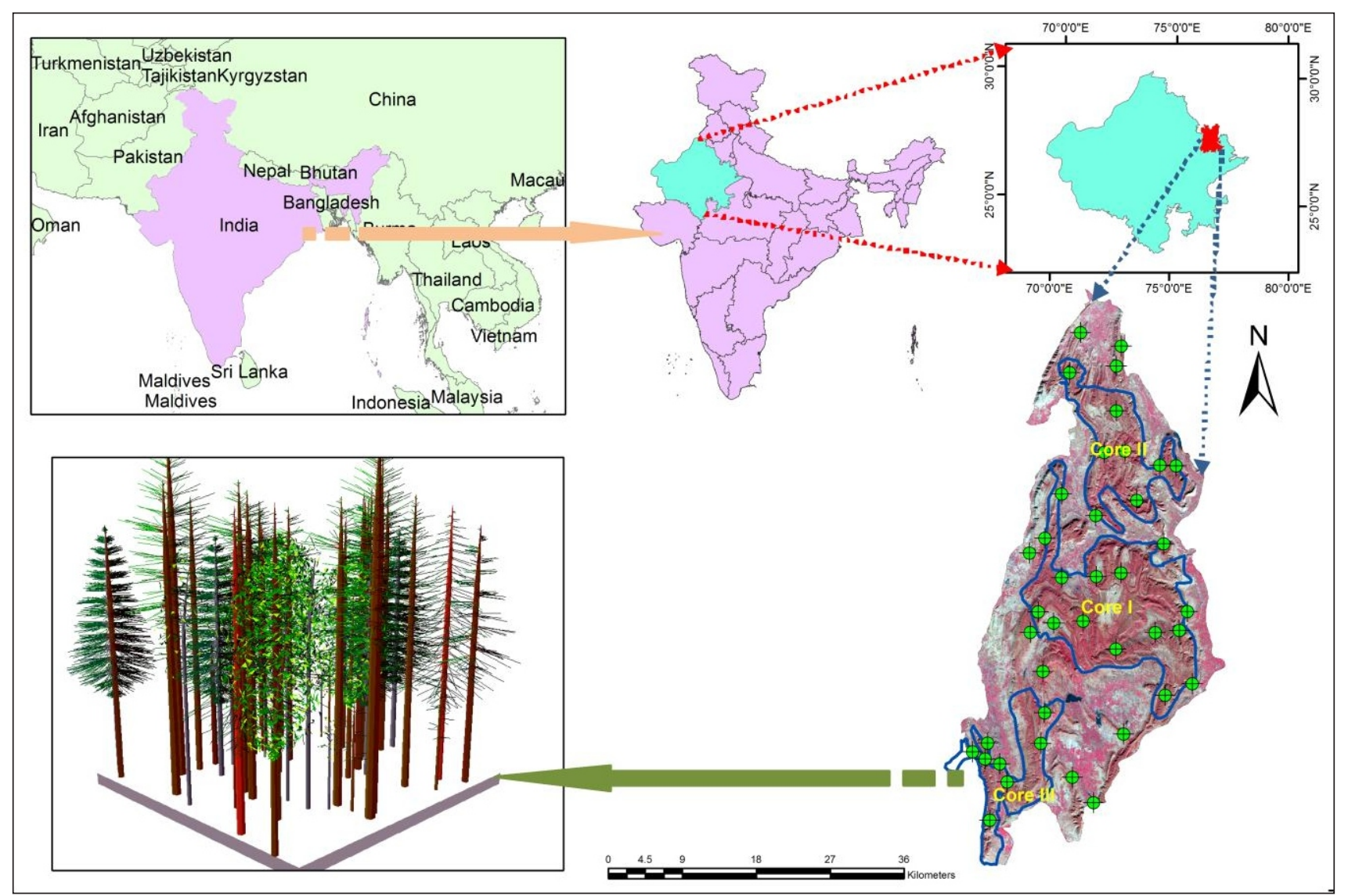

Figure1: Map of Study area

but it is not that only tigers are found here, this national park of India has always been a natural habitat of wildlife, and among these wildlife Some are predatory animals and some are prey animals. Among the wildlife found here, you get to see magnificent wildlife like wild cat, Indian leopard, golden jackal, nilgai, striped hyena, caracal, wild boar, deer, fox, sambar, chital, rhesus macaque, langur. The environment of this sanctuary is very favorable for bird habitat. In this park you can find a confluence of migratory and native birds. Indian peacock, bush quail, goldenbacked woodpecker, Indian eagle-owl, gray partridge, white-throated kingfisher, Native and exotic birds such as trepees, sandgrass, crested snake eagles are seen.

\section{Primary hetrotrophs}

The herbivorous animals or the primary consumers which depends on the producers in the preceding paragraphs are Sambhar, Nilgai, Chital, Wildboar and Chausingha. They are distributed through out of area. Their distribution pattern is governed by the food habits. Deep dense woody areas mainly in the valleys like kalighati, Silibery, Jhaj, Naldeshwar Panidhal, Bandipul etc. are occupied by the Sambher while outskirts of these valleys which are having plain land with modest slop are liked by the Chital, Nilgai and Wild boar. The Langur (Presbytis entellus Eschsch.) is common through forest but their concentration is near temples.

\section{Secondary hetrotrophs}

The Leopard (Panthera pardus L.) and Tiger (Panthera tigris L.) are the principle predators. Important niches of tigers are Bandipur, Algwal, Tarunda, Tunda Chhalipaj, Chamoli, Slopka, Kalighati and Jahaj. The Leopard prefers outskirts of the forest tract but also in the tiger niches. Though the vegetation is not very dense here you are unlikely to spot tigers in the daytime as the tigers at Sariska are nocturnal creatures. Sariska national park is home to numerous carnivores, including Rusty Spotted Cat (Prionailurus rubiginosus L.), Jackal (Canis aureus L.), Leopard (Panthera pardus L.), Caracal (Caracal caracal Schreb.), Jungle Cat (Felis chaus Schreb.), Tiger (Panthera tigris L.), Hyena (Hyaena hyaena) and Wild Dog (Cuon alpinus Pallas.). These feed on an abundance of prey species such as Sambar (Rusa unicolor Kerr.), Cheetal (Axis axis Erxleben.), Nilgai (Boselaphus tragocamelus Pallas.), Chausingha (Tetracerus quadricornis Blainville.), Wild Boar (Sus scrofa L.), Civet (Viverricula indica Dasmerest.), Palm Civet (Paradoxurus 
hermaphroditus Pallas.) Sariska is also well known for its large population of Rhesus Monkeys (Macaca mulatta Zimmermann), which are found in large numbers around Talvriksh. The avian world includes the Great Indian Horned Owl (Bubo bubo L.) Peafowl (Pavo cristatus L.),
Grey Partridge (Perdix perdix L.), Golden backed Wood Pecker (Dinopium benghalense L.), Bush Quail (Perdicula asiatica Sykes.), Sand Grouse (Pterocles indicus Gmel.), Crested Serpent Eagle (Spilornis cheela Latham) and Tree Pie (Dendrocitta vagabunda Latham) (Figure 2).

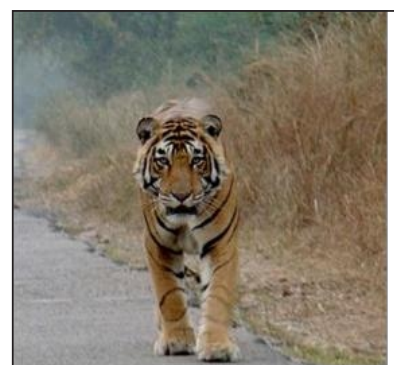

Tiger

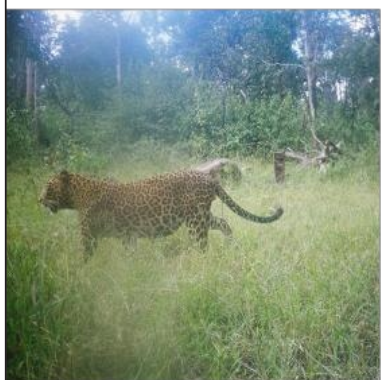

Leopard

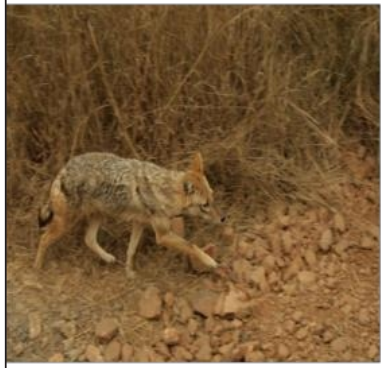

Jackal

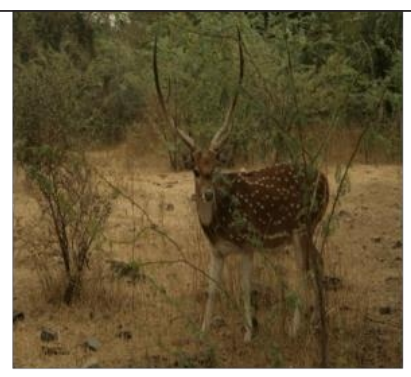

Sambar

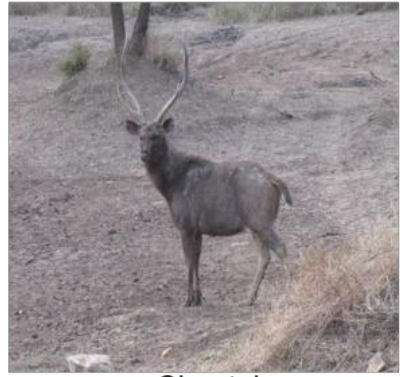

Cheetal

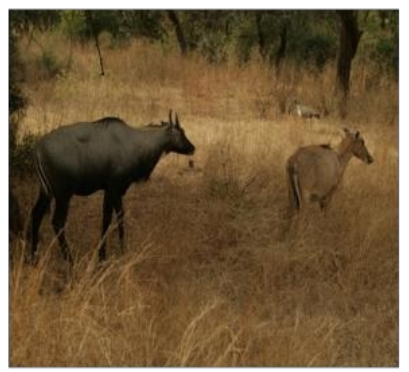

Nilgai and peafowl

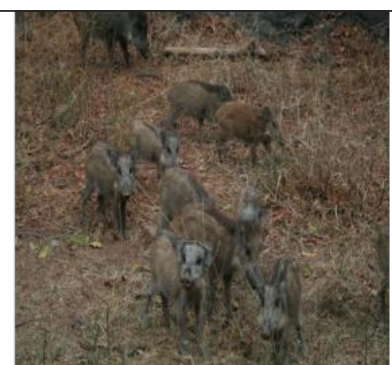

Wild Boar

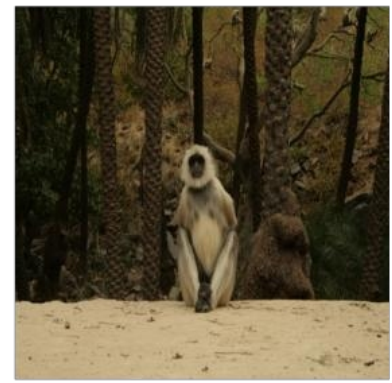

Langur

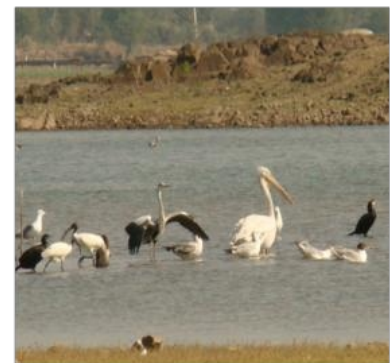

Water birds

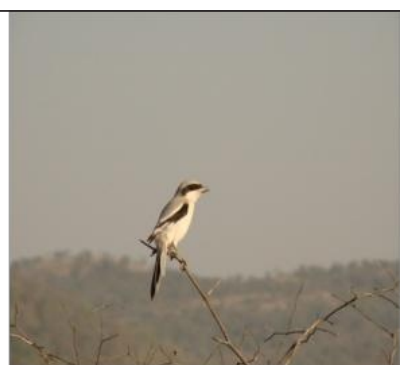

Strike

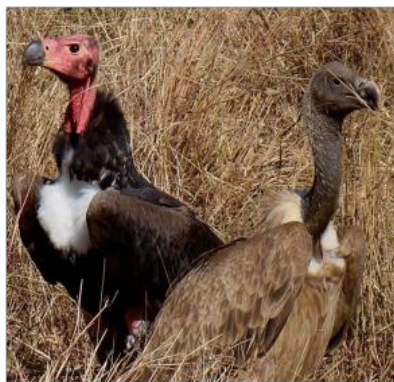

Vulture

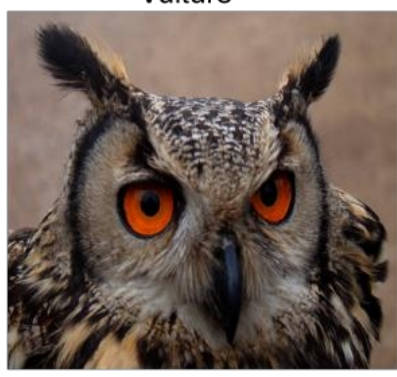

Owl

Figure 2: Faunal diversity in Sariska Tiger Reserve.

\section{Community and wildlife conflict}

Very high anthropogenic disturbances due to large number of villages in core and adjoining areas, organized poaching, high pilgrimage, state highways passing through the core area, low strength of frontline staff for enforcement, lack of commitment and careless approach were some of the identified factors responsible for local extinction of tigers. Local people also move in and out Sariska extensively, as selling livestock milk is the primary economic activity. Consequently, livestock graze and fodder is collected from inside Sariska and the buffer daily (Jain and Sajjad, 2016). These and other pressures (e.g., highway traffic, pilgrimage traffic, village relocation, tree felling) continue to impact Sariska (Johnsingh \&
Madhusudan, 2009). About 2254 families live in the core area while about 12000 families live around the Critical Tiger Habitat (Garcia and Armbruster, 1997; Gerrad et al., 2001; Gurnell et al., 2002) thus making this reserve as human dominated landscape that is subjected to immense anthropogenic pressures. Tigers only have $50 \mathrm{~km} 2$ of the $882 \mathrm{~km} 2$ reserve to themselves due to villages inside Sariska and other anthropogenic pressures (Sebastian, 2016).

Some researchers with a political ecologist view attribute the poor performance to the failure to devolve authority to local communities and unequal distribution of tangible economic benefits around PAs (Heglund, 2002; Jessup, 
1998; Kamat, 1986; Keith et al., 2008). On the contrary, biologists claim that wildlife species are at risk if local people are given more priority over conservation objectives. (T Kelly and Goulden, 2008; Kushwaha et al., 2004; Kushwaha et al. 2004). But the general consensus is that such projects if successful, would lead to better support from local communities towards conservation. Non-recognition of community role by state in conservation has led to conflicts over land and poachers took the opportunity of it. Also, human-tiger conflict is a major problem. The future of conservation now depends on solutions that minimize these conflicts.

\section{Wildlife policies and implication in India}

Enforcement of various wildlife and forests laws in any protected area is the key to the protection of biological diversity of the area. Although many studies have been done in Sariska tiger reserve focusing mainly on the ecological, biological and technical aspects of floral and faunal components of the landscape (Sankar and Johnsingh, 2002: Lai et al., 2000; Lancia et al., 1982; Larson et al., 2003; Luck, 2002b; Lurz et al., 2008; Osborn et al., 2001; Ozesmi and Mitsch, 1997) or critical review of the working of forest department with local communities (Radeloff et al., 1999; Rittenhouse et al., 2006; Schamberger et al., 1982) but the studies related to wildlife law enforcement are still lacking.Despite challenges associated with patrolling vast landscapes (Schamberger and O'Neil, 1986; Senapathi et al., 2007), research suggests that frontline law enforcement presence is necessary to curb wildlife crimes (Shalaby et al., 2007).Wildlife Protection Act, 1972 is comprehensive enough to tackle the crisis with regard to wild life protection. However, it is believed that, in spite of having comprehensive legislation, there is no sign of reduction in the poaching of wild animals and other offences related to habitat destruction in many of PAs, therefore, it can be concluded that enforcement mechanism is suffering decay from within (Store and Jokimäki, 2003). Accordingly, it raises the question with regard to effective implementation of the provisions of wildlife law. The draft National Tourism Policy of 1997 in India, speaks of "maintaining a judicious balance between conservation and development". The policy addresses social and environmental impacts and also suggests guidelines for sustainable growth, but does not discuss the legal or institutional framework for activities that would contribute to sustainable development, for example wildlife tourism, or the role of local communities in tourism development. It is also seen that the enforcement mechanism of the laws in India for the conservation and protection of wildlife is also complicated in nature. The laws, on one hand, enable the forest officers to protect the forests resources, but they are not given any powers to make policies pertaining to the situation which further creates problems in the confiscation of the felled timber or the poached animal. It was concluded that the protection of forest and wildlife depends on the efficient enforcement of meticulous provisions by the enforcement agencies (Poddar, 2017). Implementation of existing forest and wildlife laws in a protected area or a tiger reserve is the determining factor for the long term conservation of biological diversity of that area.

Wildlife policies are typically motivated by the wildlife species imposing an external cost of some kind, e.g., on agricultural or forestry production, or by the species providing benefits that have public good characteristics, e.g., if the species is threatened and its preservation is considered highly valuable. There is a large body of literature on voluntary cooperation on management of natural resources, but we have not found applications to wildlife resources in this regard. However, conditions for successful voluntary cooperation are restrictive, and governmental interventions with coercive power are often needed for improved management.

\section{CONCLUSION}

Local communities are vulnerable to the establishment of protected areas, particularly in developing countries since their livelihoods are dependent on them. They pay indirectly not only by loss of access to resources like fuel wood, fodder and other non-timber forest products, but often by direct losses from crop and livestock raiding by wild animals dispersing from protected areas. Some researchers with a political ecologist view attribute the poor performance to the failure to devolve authority to local communities and unequal distribution of tangible economic benefits around protected areas. On the contrary, biologists claim that wildlife species are at risk if local people are given more priority over conservation objectives. Linking communities with conservation goal can be a viable option however, linking economic benefits to conservation is difficult where wildlife is highly endangered, pressure on biomass resources is high, and stakeholders are many.

\section{REFERENCE}

1. Aspinall, R., \& Veitch, N. (1993). Habitat mapping from satellite imagery and wildlife survey data using a Bayesian modeling procedure in a GIS. Photogrammetric engineering and remote sensing, 59(4), 537-543.

2. Bian, L., \& West, E. (1997). GIS modeling of elk calving habitat in a prairie environment with statistics. Photogrammetric Engineering and Remote Sensing, 63(2), 161-167. 
3. Brooks, R. P. (1997). Improving habitat suitability index models. Wildlife Society Bulletin, 163-167.

4. Butfiloski, J. W., Hall, D. I., Hoffman, D. M., \& Forster, D. L. (1997). White-tailed deer management in a coastal Georgia residential community. Wildlife Society Bulletin, 491-495.

5. Chang, T. H., \& Wang, T. C. (2009). Using the fuzzy multi-criteria decision making approach for measuring the possibility of successful knowledge management. Information sciences, 179(4), 355-370.

6. Conner, L. M., \& Leopold, B. D. (1998). A multivariate habitat model for female bobcats: a GIS approach. In Proceedings of the annual conference of the Southeastern Association of Fish and Wildlife Agencies (Vol. 52, pp. 232-243).

7. Debeljak, M., Džeroski, S., Jerina, K., Kobler, A., \& Adamič, M. (2001). Habitat suitability modelling for red deer (Cervus elaphus L.) in South-central Slovenia with classification trees. Ecological modelling, 138(1-3), 321-330.

8. Donovan, M. L., Rabe, D. L., \& Olson, C. E. (1987). Use of geographic information systems to develop habitat suitability models. Wildlife Society Bulletin (1973-2006), 15(4), 574-579.

9. Edenius, L., \& Mikusiński, G. (2006). Utility of habitat suitability models as biodiversity assessment tools in forest management. Scandinavian Journal of Forest Research, 21(S7), 62-72.

10. Garcia, L. A., \& Armbruster, M. (1997). A decision support system for evaluation of wildlife habitat. Ecological modelling, 102(2-3), 287-300.

11. Gerrard, R., Stine, P., Church, R., \& Gilpin, M. (2001). Habitat evaluation using GIS: a case study applied to the San Joaquin kit fox. Landscape and Urban Planning, 52(4), 239-255.

12. Gurnell, J., Clark, M. J., Lurz, P. W., Shirley, M. D., \& Rushton, S. P. (2002). Conserving red squirrels (Sciurus vulgaris): mapping and forecasting habitat suitability using a Geographic Information Systems Approach. Biological conservation, 105(1), 53-64.

13. Gurnell, J., Clark, M. J., Lurz, P. W., Shirley, M. D., \& Rushton, S. P. (2002). Conserving red squirrels (Sciurus vulgaris): mapping and forecasting habitat suitability using a Geographic Information Systems Approach. Biological conservation, 105(1), 53-64.

14. Verberk, W. C., Van Noordwijk, C. G. E., \& Hildrew, A. G. (2013). Delivering on a promise: integrating species traits to transform descriptive community ecology into a predictive science. Freshwater Science, 32(2), 531-547.

15. Jain, P., \& Sajjad, H. (2016). Household dependency on forest resources in the Sariska Tiger Reserve (STR), India: Implications for management. Journal of Sustainable Forestry, 35(1), 60-74.

16. Jhala, Y. V., Qureshi, Q., Gopal, R., \& Sinha, P. R. (2015). The Status of Tigers in India 2014. National Tiger Conservation Authority.

17. Johnsingh, A. J. T., Sankar, K., \& Mukherjee, S. (1997). Saving prime tiger habitat in Sariska Tiger Reserve. Cat News, 27(3).

18. Kumar, P., Sharma, L. K., Pandey, P. C., Sinha, S., \& Nathawat, M. S. (2013). Geospatial strategy for forest biomass estimation of tropical forest of Sariska Wildlife Reserve (India). IEEE J. Sel. Topics Appl. Earth Observat. Remote Sens., 6(2), 917-923.

19. Kushwaha, S. P. S., Munkhtuya, S., \& Roy, P. S. (2001). Mountain goat habitat evaluation in Rajaji National Park using remote sensing and GIS. J Indian Soc Remote Sens, 28, 293-303.

20. Kushwaha, S. P. S., Munkhtuya, S., \& Roy, P. S. (2000). Geospatial modelling for goral habitat evaluation. Journal of the Indian Society of Remote Sensing, 28(4), 293-303.

21. Lai, Y., Mills, L. W., \& Cheng, C. (2000). Implementation of a geographic information system (GIS) to determine wildlife habitat quality using habitat suitability index. GIS Development Net, The Asian GIS Portal.

22. Lancia, R. A., Miller, S. D., Adams, D. A., \& Hazel, D. W. (1982). Validating habitat quality assessment: an example [Management of wildlife resources, USA]. In Transactions of the North American Wildlife and Natural Resources Conferences.

23. Larson, M. A. (2003). Landscape-level habitat suitability models for twelve wildlife species in southern Missouri (Vol. 233). US Department of Agriculture, Forest Service, North Central Research Station.

24. Larson, M. A. (2003). Landscape-level habitat suitability models for twelve wildlife species in southern Missouri (Vol. 233). US Department of Agriculture, Forest Service, North Central Research Station.

25. Luck, G. W. (2002). The habitat requirements of the rufous treecreeper (Climacteris rufa). 1. Preferential habitat use demonstrated at multiple spatial scales. Biological Conservation, 105(3), 383-394. 
26. Lurz, P. W. W., Koprowski, J. L., \& Wood, D. J. A. (2008). The use of GIS and modelling approaches in squirrel population management and conservation: a review. Current Science, 918-922.

27. Osborne, P. E., Alonso, J. C., \& Bryant, R. G. (2001). Modelling landscape-scale habitat use using GIS and remote sensing: a case study with great bustards. Journal of applied ecology, 38(2), 458-471.

28. Özesmi, U., \& Mitsch, W. J. (1997). A spatial habitat model for the marsh-breeding red-winged blackbird (Agelaius phoeniceus L.) in coastal Lake Erie wetlands. Ecological Modelling, 101(2-3), 139-152.

29. Kumar, P., Sajjad, H., Tripathy, B. R., Ahmed, R., \& Mandal, V. P. (2018). Prediction of spatial soil organic carbon distribution using Sentinel-2A and field inventory data in Sariska Tiger Reserve. Natural Hazards, 90(2), 693-704.

30. Kumar, P., Sajjad, H., Mahanta, K. K., Ahmed, R., \& Mandal, V. P. (2018). Assessing suitability of allometric models for predicting stem volume of Anogeissus pendula Edgew in sariska Tiger Reserve, India. Remote Sensing Applications: Society and Environment, 10, 47-55.

31. Kumar, P., Tomar, V., Srivastava, P., Singh, J., \& Gupta, G. (2014). Geospatial approach for carbon sink in the timbered biomass for tropical wildlife reserve. Asian Journal of Geoinformatics, 14(1).

32. Kumar, P., Pandey, P. C., Kumar, V., Singh, B. K., Tomar, V., \& Rani, M. (2014). Efficient recognition of forest species biodiversity by inventory based geospatial approach using LISS IV. Sensors Journal, IEEE, 13(6), 2161-2165.

33. Radeloff, V. C., Pidgeon, A. M., \& Hostert, P. (1999). Habitat and population modelling of roe deer using an interactive geographic information system. Ecological Modelling, 114(2-3), 287-304.

34. Senapathi, D., Vogiatzakis, I. N., Jeganathan, P., Gill, J.A., Green, R. E., Bowden, C. G., ... \& Norris, K. (2007). Use of remote sensing to measure change in the extent of habitat for the critically endangered Jerdon's Courser Rhinoptilus bitorquatus in India. Ibis, 149(2), 328-337.

35. Rani, M., Kumar, P., Yadav, M., \& Hooda, R. S. (2011). Role of geospatial techniques in forest resource management of Sariska Tiger Reserve
(Rajasthan), India. New York Science Journal, 4(6), 77-82.

36. Reddy, P. A., Cushman, S. A., Srivastava, A., Sarkar, M. S., \& Shivaji, S. (2017). Tiger abundance and gene flow in Central India are driven by disparate combinations of topography and land cover. Diversity and Distributions, 23(8), 863-874.

37. Keith, D. A., Akçakaya, H. R., Thuiller, W., Midgley, G. F., Pearson, R. G., Phillips, S. J., ... \& Rebelo, T. G. (2008). Predicting extinction risks under climate change: coupling stochastic population models with dynamic bioclimatic habitat models. Biology letters, 4(5), 560-563.

38. Rittenhouse, C. D. (2007). Development of landscape-level habitat suitability models for ten wildlife species in the central hardwoods region (Vol. 4). US Department of Agriculture, Forest Service, Northern Research Station.

39. Roy, P. S., Ravan, S. A., Rajadnya, N., Das, K. K., Jain, A., \& Singh, S. (1995). Habitat suitability analysis of Nemorha.

40. Sankar, K., Qureshi, Q., Nigam, P., Malik, P. K., Sinha, P. R., Mehrotra, R. N., ... \& Gupta, S. (2010). Monitoring of reintroduced tigers in Sariska Tiger Reserve, Western India: preliminary findings on home range, prey selection and food habits. Tropical Conservation Science, 3(3), 301-318.

41. Schamberger, M., \& O'Neil, J. (1986). Concepts and constraints of habitat model testing.

42. Singh, G., Velmurugan, A., \& Dakhate, M. P. (2009). Geospatial approach for tiger habitat evaluation and distribution in Corbett Tiger Reserve, India. Journal of the Indian Society of Remote Sensing, 37(4), 573-585.

43. Tanushree, S. (2009). Relocation of villages in Sariska Tiger Reserve. Current Science, 97(10), 13991400 .

44. Store, R., \& Jokimäki, J. (2003). A GIS-based multiscale approach to habitat suitability modeling. Ecological modelling, 169(1), 1-15.

45. Walston, J., Robinson, J. G., Bennett, E. L., Breitenmoser, U., da Fonseca, G. A., Goodrich, J., ... \& Wibisono, H. (2010). Bringing the tiger back from the brink - the six percent solution. PLoS Biol, 8(9), e1000485. 